\title{
PROFIL JAPANESE CLUB SEBAGAI KEGIATAN EKSTRAKIRUKULER SMK NUSA DUA TOYA ANYAR KUBU
}

\author{
I. K. S. Putra ${ }^{1}$, N. N. Suartini ${ }^{2}$, I. W. Sadyana ${ }^{3}$ \\ ${ }^{123}$ Jurusan Pendidikan Bahasa Jepang, Universitas Pendidikan Ganesha, Singaraja \\ e-mail: komangsertiana@gmail.com, nnsuartini@undiksha.ac.id, wayan.sadyana@undiksha.ac.id
}

\begin{abstract}
Abstrak
Penelitian ini bertujuan untuk mendseskripsikan (1) pembelajaran ekstrakurikuler Japanese Club, (2) kendala-kendala yang dihadapi dalam kegiatan ekstrakurikuler Japanese Club dan (3) upaya yang dilakukan dalam mengatasi kendala-kendala dalam pembelajaran ekstrakurikuler Japanese Club di SMK Nusa Dua Toya Anyar Kubu. Subjek penelitian ini yaitu guru pembina ekstrakurikuler Japanese Club di SMK Nusa Dua Toya Anyar Kubu. Metode pengumpulan data yang digunakan yaitu observasi, wawancara dan dokumentasi. Hasil penelitian ini menunjukkan (1) pembelajaran ekstrakurikuler Japanese Club di SMK Nusa Dua Toya Anyar memuat pemilihan konten materi yang masih berhubungan dengan materi yang pernah diajarkan sebelumnya pada mata pelajaran bahasa Jepang, dan bahan ajar dirancang secara mandiri oleh guru atau diperoleh dari berbagai sumber, penggunaan metode pembelajaran seperti Grammar Translation Method, penggunaan strategi pembelajaran seperti ceramah, pemberian tugas, information gap, drill, dan role play, serta penggunaan media pembelajaran. (2) Kendala-kendala yang dihadapi guru dalam kegiatan ekstrakurikuler bahasa Jepang antara lain sarana dan prasarana, alokasi waktu, penguasaan materi oleh siswa, kemampuan guru dalam pengelolaan kelas dan motivasi siswa, serta (3) Upaya yang dilakukan untuk mengatasi kendala pembelajaran dengan cara pembangunan ruangan praktik oleh sekolah, melakukan penugasan, mengatur siswa antar jurusan untuk duduk berpasangan, memberikan teguran bagi siswa yang tidak disiplin, dan memotivasi siswa tentang pentingnya belajar bahasa asing.
\end{abstract}

Kata kunci: pembelajaran, profil, ekstrakurikuler

\begin{abstract}
要旨
本研究は、（1）私立トヤ・アニャル・クブ職業高校において実施される「日本語クラブ」課 外授業の実態報告、（2）同授業における当校教師の様々な問題点、（3） その問題点に対す る解決法を明らかにしたものである。対象は、同校「日本語クラブ」課外授業を担当する教師 である。データは、観察、インタビュー、撮影により収集した。結果、（1）私立トヤ・アニ ヤル・クブ職業高校「日本語クラブ」課外授業において、学習内容は使用する日本語の教科書 以外から選択し、その際身体反応教授法及び文法翻訳教授法が使用される。また、学習法とし て解説、課題、インフォメーションギャップ、ドリル、ロールプレイが使用され、会話練習が 実施される。教材は、数字カード、スピーカー、液晶プロジェクターが使用される。（2）課 外授業における問題点として、施設とインフラ、学習時間、学生の指導内容の理解能力、教室 の管理、学生の動機が挙げられる。（3）問題点の解決方法として、練習室の建設、課題提出 学生が専攻の間にペアで座席、聴解困難な場合の読み取り、外国語を学ぶことの重要性を刺 激する。
\end{abstract}

キーワード：課外授業、学習

\section{Pendahuluan}

Sebagai salah satu lembaga penyelenggara pendidikan, sekolah memiliki ciri-ciri tertentu yang membedakan sekolah dengan lembaga penyelenggara pendidikan lainnya. Ciri khas dari sekolah yaitu terjadinya proses belajar mengajar, interaksi antara guru dan siswa, dan terdapat wadah untuk mengembangkan karakter dan potensi yang dimiliki siswa.

Keberadaan kegiatan ekstrakurikuler sangatlah penting karena sekolah dapat memberikan kesempatan bagi peserta didik untuk mengembangkan potensi, minat, bakat, dan hobi yang dimiliki siswa. Dalam hal ini, guru atau tenaga pengajar memiliki peran yang 
sangat penting dalam meyalurkan bakat dan potensi siswa. Kegiatan ekstrakurikuler tidak akan berhasil apabila tidak dikelola dengan baik oleh sekolah.

Pengelolaan kegiatan ekstrakurikuler yang dilakukan secara efektif tidak hanya dapat mendukung keberhasilan program intrakurikuler ataupun kokurikuler, namun juga dapat mendukung keberhasilan pendidikan secara luas. Integrasi ketiga jenis kegiatan ini tidak hanya dilakukan untuk menunjang dan meningkatkan pemahaman siswa, namun juga membentuk karakter siswa yang mandiri dan berwawasan luas. Apabila proses pembelajaran kegiatan ekstrakurikuler dapat diterapkan dengan baik dan menggunakan metode maupun strategi pembelajaran yang tepat, maka tujuan pendidikan akan dapat tercapai secara maksimal.

SMK Nusa Dua Toya Anyar Kubu adalah salah satu Sekolah Menengah Kejuruan di kabupaten Karangasem yang memiliki beragam jenis ekstrakulikuler. Kegiatan klub ekstrakurikuler yang dimiliki tidak hanya bersifat hobi atau kegemaran, tetapi juga berkaitan dengan mata pelajaran yang ada di kelas. SMK Nusa Dua Toya Anyar Kubu merupakan sekolah yang tidak hanya menjadikan bahasa Jepang sebagai program intrakurikuler, tetapi juga menjadikan bahasa Jepang sebagai kegiatan ekstrakurikuler. Ekstrakurikuler Japanese Club di SMK Nusa Dua Toya Anyar Kubu dibentuk sebagai wadah untuk menampung minat dan bakat siswa dan mengasah potensi yang dimiliki oleh peserta didik di bidang bahasa Jepang. Peserta didik diarahkan untuk berkreasi dan berpikir kreatif, sehingga tujuan untuk menghasilkan sumber daya manusia yang terampil bisa berjalan dengan optimal.

Kegiatan ekstrakurikuler Japanese Club di SMK Nusa Dua Toya Anyar Kubu seharusnya menjadi tempat yang baik untuk mengembangkan minat dan bakat siswa, tetapi masih terdapat sejumlah kendala yang ditemui selama proses pelaksanaannya.

Untuk mengatasi permasalahan tersebut, diperlukan suatu inovasi dalam penyajian kegiatan ekstrakurikuler di sekolah berupa penerapan metode, strategi, dan pemanfaatan media yang dapat mendukung kelancaran proses kegiatan. Kreatifitas pengajar dalam memilih strategi dan metode yang tepat sangat diperlukan, sehingga kegiatan ekstrakurikuler bisa berjalan dengan optimal dan sesuai dengan rencana. Pemahaman yang mendalam tentang strategi ataupun metode yang dapat digunakan pada saat mengajar untuk mengatasi permasalahan dan kendala yang dialami pada saat kegiatan ekstrakurikuler secara umum maupun secara khusus pada kegiatan ekstrakurikuler Japanese Club di SMK Nusa Dua Toya Anyar Kubu menjadi faktor penting penelitian ini dilakukan.

Berdasarkan uraian diatas, diadakan suatu penelitian tentang pembelajaran ekstrakurikuler Japanese Club di SMK Nusa Dua Toya Anyar Kubu, seperti kegiatan yang dilakukan serta metode dan strategi yang digunakan oleh guru untuk mengatasi kendala yang ditemui dalam mengajar ekstrakurikuler.

Dengan melakukan beberapa variasi beberapa metode dan strategi pembelajaran, maka diharapkan proses pembelajaran yang berlangsung tidak membosankan bagi pembelajar, serta dapat mengatasi masalah yang dihadapi oleh pengajar pada situasi dan kondisi tertentu dalam melaksanakan kegiatan belajar, khususnya bahasa asing.

Grammar translation method merupakan metode pembelajaran yang berpusat pada guru. Guru menggunakan metode ini untuk memusatkan perhatian siswa pada kosakata dan tatabahasa dengan membaca teks yang dilengkapi dengan terjemahannya dalam bahasa pertama/bahasa ibu siswa (Larsen-Freeman, 2000).

Strategi ceramah digunakan untuk menyampaikan keterangan, informasi atau uraian tentang suatu pokok persoalan serta masalah secara lisan (Roestiyah, 2008:136). Strategi ini digunakan oleh guru agar guru lebih mudah mengawasi ketertiban siswa dalam menyimak pelajaran, dikarenakan para siswa melakukan kegiatan yang sama.

Drill adalah strategi dalam pengajaran dengan melatih peserta didik terhadap bahan yang sudah diajarkan atau yang suda diberikan agar memiliki keterampilan dari yang sudah dipelajari. Drill biasanya digunakan dengan tujuan agar siswa memliki keterampilan motoris/gerak seperti menghafalkan kata-kata, menulis dan mempergunakan alat (Roestiyah. 2008:136).

Information gap adalah strategi pembelajaran di mana siswa berkewajiban bekerja secara berpasangan. Satu siswa memiliki informasi sementara satu siswa yang lain tidak mempunyai informasi. Mereka harus saling menukar informasi yang dimiliki. Setiap pasangan harus memiliki peran yang sangat penting, sebab lugas tidak dapat diselesaikan 
jika pasangan tidak dapat memberikan informasi kepada yang lain (Kayi, 2006).

Penugasan diberikan untuk mengatasi banyaknya kegiatan pendidikan di sekolah, karena menyita waktu siswa untuk melaksanakan kegiatan belajar mengajar (Roestiyah, 2008:132). Tugas dapat diberikan dalam bentuk tugas tertulis atau lugas lisan sesuai dengan kebutuhan pelajaran.

Role-playing atau bermain peran adalah strategi pembelajaran yang diarahkan untuk mengkreasi peristiwa sejarah, peristiwa aktual, atau kejadian yang mungkin muncul pada masa mendatang (Baroroh, 2011:149). Role-playing digunakan untuk meningkatkan karakter disiplin, kreatifitas, kerja keras, dan kemampuan komunikasi di kelas.

Penelitian relevan yang dilakukan adalah penelitian dari Meriani (2017). Penelitian tersebut mendeskripsikan tentang pembelajaran ekstrakurikuler Bahasa Jepang di SMA Negeri 1 Seririt, kendala-kendala yang dihadapi, dan solusi yang ditempuh dalam mengatasi kendala-kendala tersebut. Hasil dari penelitian Meriani (2017) tersebut menunjukkan bahwa pembelajaran ekstrakurikuler bahasa Jepang di SMA Negeri 1 Seririt meliputi pemilihan konten materi yang melibatkan peserta didik, dan dirancang oleh guru secara mandiri dengan mengolah materi yang didapat dari berbagai sumber. Kendala-kendala yang dihadapi selama kegiatan ekstrakurikuler Bahasa Jepang di SMA Negeri 1 Seririt antara lain keterbatasan media pembelajaran di sekolah, kurangnya penguasaan materi ajar, kendala dalam mengelola kelas, serta alokasi waktu. Sedangkan cara yang ditempuh untuk mengatasi kendala-kendala tersebut yaitu dengan memanfaatkan pengeras suara dan smartphone sebagai media pembelajaran, mengulang kembali materi pembelajaran sebelumnya, melakukan teguran apabila ada siswa yang kurang disiplin, dan memberikan tambahan alokasi waktu untuk mengatasi kendala kurangnya waktu.

\section{Metode}

Penelitian ini mengggunakan metode deskriptif kualitatif. Penelitian ini akan mendeskripsikan secara kualitatif tentang profil kegiatan ekstrakurikuler Japanese Club di SMK Nusa Dua Toya Anyar Kubu. Penelitian ini dilakukan di SMK Nusa Dua Toya Anyar yang terletak di desa Tianyar, Kecamatan Kubu, Kabupaten Karangasem.

Subjek dalam penelitian ini adalah guru yang mengajar ekstrakulikuler Japanese Club di SMK Nusa Dua Toya Anyar. Guru pembina kegiatan ekstrakurikuler tersebut bernama I Made Putu Ariawan. Beliau telah menjadi Pembina kegiatan ekstrakurikuler Japanese Club di SMK Nusa Dua Toya Anyar sejak tahun 2009.

Sementara itu, objek penelitian antara lain (1) pembelajaran ekstrakurikuler Japanese Club yang ada di SMK Nusa Dua Toya Anyar, (2) kendala-kendala yang dihadapi dalam ekstrakurikuler Japanese Club di SMK Nusa Dua Toya Anyar, (3) upaya yang dilakukan untuk mengatasi kendala-kendala yang dihadapi pada kegiatan ekstrakurikuler Japanese Club di SMK Nusa Dua Toya Anyar. Ketiga hal tersebut termasuk dalam objek penelitian karena merupakan sasaran utama pada penelitian ini.

Adapun metode pengumpulan data yang digunakan dalam penelitian ini adalah metode observasi, wawancara dan dokumentasi. Metode observasi digunakan untuk mencari dan mendapatkan data terkait profil ekstrakurikuler Japanese Club yang ada di SMK Nusa Dua Toya Anyar. Observasi yang dilakukan merupakan observasi non-partisipan saat proses belajar mengajar di kelas.

Metode pengumpulan data dengan wawancara dilakukan dengan melakukan wawancara kepada guru Pembina kegiatan ekstrakurikuler Japanese Club di SMK Nusa Dua Toya Anyar. Dalam penelitian ini, wawancara yang digunakan adalah jenis wawancara terstruktur karena format wawancara yang berkaitan dengan pembelajaran ekstrakulikuler Japanese Club di SMK Nusa Dua Toya Anyar sudah disiapkan sebelum wawancara dilakukan.

Data yang dikumpulkan berupa bahan ajar atau materi yang digunakan, LKS (Lembar Kerja Siswa) dan foto dokumentasi kegiatan pembelajaran di dalam kelas. Dengan demikian, akan diketahui proses pembelajaran kegiatan ekstrakurikuler Japanese Club di SMK Nusa Dua Toya Anyar.

Analisis data ini dilakukan sesuai dengan tujuan penelitian itu sendiri, yaitu peneliti ingin mengetahui pembelajaran bahasa Jepang sebagai kegiatan ekstrakurikuler Japanese Club di SMK Nusa Dua Toya Anyar. Prosedur yang ditempuh dalam menganalisis data pada 
penelitian ini yakni (1) tabulasi data, (2) reduksi data, (3) deskripsi data, (4) klasifikasi data, dan (5) penarikan kesimpulan.

\section{Hasil dan Pembahasan}

Data ini diambil melalui hasil observasi dan hasil wawancara dideskripsikan sesuai dengan fakta yang ditemukan di lapangan. Pendeskripsian ini dilakukan berdasarkan sub masalah yang telah dipaparkan dalam rumusan masalah.

Berdasarkan hasil observasi yang dilakukan sebanyak empat kali, ditemukan bahwa untuk mencapai sasaran dan tujuan pembelajaran yang diharapkan, guru pembina ekstrakurikuler mempersiapkan dan melakukan proses pembelajaran sesuai dengan tujuan pembelajaran dengan cara menggunakan bahan ajar, metode pembelajaran, strategi pembelajaran, media dan lain-lain dalam membina ekstrakurikuler Japanese Club di SMK Nusa Dua Toya Anyar.

Dalam mengajar ekstrakurikuler Japanese Club di SMK Nusa Dua Toya Anyar, guru pembina ekstrakurikuler tidak menggunakan Rencana Pelaksanaan Pembelajaran (RPP) seperti pada pembelajaran bahasa Jepang secara intrakurikuler. Oleh sebab itu guru tidak menggunakan buku panduan atau buku penunjang yang tetap. Alasan lainnya adalah karena para siswa yang tergabung dalam kegiatan ekstrakurikuler Japanese Club berasal dari kelas jurusan yang berbeda-beda.

Setiap siswa memiliki tingkat kemampuan yang berbeda dalam menyerap materi dikarenakan mereka berasal dari jurusan yang berbeda. Mata pelajara bahasa Jepang sebagai program intrakurikuler hanya diberikan pada jurusan Perhotelan kelas $\mathrm{X}$, sehingga siswa tidak memiliki dasar pemahaman yang sama dalam pembelajaran bahasa Jepang. Agar siswa yang bukan berasal dari jurusan Perhotelan dapat mengimbangi kemampuan siswa yang berasal dari jurusan Perhotelan, guru sebagai pembina ekstrakurikuler akan mengulang kembali materi yang dianggap perlu pada mata pelajaran Bahasa Jepang, terutama untuk siswa kelas X. Untuk siswa kelas XI, karena seluruh peserta tidak memeroleh mata pelajaran Bahasa Jepang secara intrakurikuler, guru pembimbing ekstrakurikuler memiliki keleluasaan dalam memilih materi.

Pemilihan bahan ajar yang berasal di luar buku penunjang juga dilakukan oleh guru pembina ekstrakurikuler. Kegiatan pembelajaran ekstrakurikuler mendukung keberhasilan dari program intrakurikuler, karena terdapat bebarapa hal atau konten materi yang telah diajarkan kemudian diulang kembali dengan teknik yang berbeda untuk memantapkan materi yang telah didapatkan pada program intrakurikuler. Dalam hal ini, guru pembina ekstrakurikuler menggunakan buku penunjang berupa buku Bahasa Jepang Untuk Hotel dan Pariwisata. Guru memilih materi sesuai dengan materi yang diperoleh siswa sebelumnya, terutama yang berhubungan dengan aspek pariwisata.

Selain itu, guru juga menggunakan lembar kerja siswa yang dibuat secara mandiri maupun diproleh dari berbagai sumber. Lembar kerja siswa bersifat ringkas sehingga mampu diperbanyak dengan mudah. Lembar kerja siswa bisa dibawa pulang oleh siswa sebagai acuan bagi mereka untuk belajar dan mengerjakan tugas.

Berdasarkan hasil observasi guru pembina esktrakurikuler Japanese Club di SMK Nusa Dua Toya Anyar Kubu menggunakan tahapan proses pembelajaran bahasa Jepang dasar. Dalam pembelajaran bahasa Jepang dasar terdapat tiga jenis tahapan pembelajaran bahasa Jepang yaitu dounyuu (latihan pengenalan), kihon renshuu (latian dasar), dan ouyou renshuu (latihan penerapan).

Guru menerapkan dounyuu dengan menggunakan bahasa ibu pelajar yaitu bahasa Indonesia. Apabila materi pada suatu pertemuan berhubungan dengan materi pada pertemuan sebelumnya, guru akan secara singkat memaparkan materi pertemuan sebelumnya, kemudian dilanjutkan dengan mengajarkan konten materi pada pertemuan tersebut.

Proses pembelajaran dilanjutkan dengan kihon renshuu atau latihan dasar yang berupa hanpuku renshuu (latihan pengulangan) dengan cara meminta siswa mengucapkan ulang kalimat yang diucapkan oleh guru dan yang terdapat pada lembar kerja siswa, dan outou renshuu (latihan kegiatan menjawab dan merespons) yang dilakukan dengan cara pemberian drill dan tanya jawab. 
Tahap selanjutnya yaitu ouyou renshuu atau latihan penerapan dilakukan dengan melakukan percakapan antara siswa dengan siswa. Siswa diminta secara berpasangan atau berkelomok untuk membuat percakapan, dan percakapan tersebut diperagakan di depan kelas.

Berdasarkan observasi yang telah dilakukan dalam kegiatan ekstrakurikuler Japanese Club di SMK Nusa Dua Toya Anyar Kubu, guru menggunakan metode Grammar Translation Method dalam mengajar. Penggunaan metode Grammar Translation Method terlihat pada saat guru menjelaskan kosakata dan pola kalimat yang digunakan. Guru memberikan arti dari kosakata baru dan penggunaan pola kalimat dalam bahasa Indonesia.

Guru Pembina kegiatan ekstrakurikuler menggunakan strategi pembelajaran berupa ceramah, diskusi, pemberian tugas, information gap, drill, dan role play untuk kegiatan praktik.

Berdasarkan sasaran yang ingin dicapai dari pelaksanaan ekstrakurikuler Japanese Club di SMK Nusa Dua Toya Anyar, guru melaksanakan tes atau penilaian setiap beberapa minggu sekali dan melakukan penilaian berdasarkan pengamatan mengenai keseharian siswa dalam mengikuti ekstrakurikuler bahasa Jepang.

Dalam proses belajar mengajar pada kegiaatan ekstrakurikuler Japanese Club di SMK Nusa Dua Toya Anyar Kubu, guru menemui beberapa kendala seperti keterbatasan sarana dan prasarana pelajaran, kendala mengenai alokasi waktu, kendala dalam penguasaan materi oleh siswa, kendala dalam mengelola kelas, dan kendala kurangnya motivasi siswa dalam mengikuti kegiatan ekstrakurikuler.

Usaha yang telah dilakukan baik pihak guru maupun sekolah dalam mengatasi kendalakendala tersebut yaitu, yang pertama untuk mengatasi kendala dalam hal keterbatasan sarana dan prasarana, sekolah telah membangun hotel, restoran, dan meja resepsionis sebagai lokasi untuk melakukan kegiatan praktek. Kendala dalam alokasi waktu mampu ditanggulangi dengan guru sesekali memberikan pengugasan yang bisa dikerjakan di rumah oleh siswa. Selain itu, guru juga sering memindahkan waktu kegiatan ekstrakurikuler apabila pertemuan pada hari yang dijadwalkan tidak bisa dilakukan. Untuk mengatasi kendala dalam penguasaan pemahaman siswa, terutama karena perbedaan jurusan, agar siswa yang bukan berasal dari jurusan yang menerima pelajaran Bahasa Jepang di kelas dapat mengimbangi kemampuan siswa lainnya, guru sebagai pembina ekstrakurikuler akan meminta siswa duduk secara berpasangan. Untuk mengatasi kendala dalam mengelola kelas, guru sebagai pembina kegiatan ekstrakurikuler berhak menegur siswa apabila terdapat siswa yang mengganggu proses belajar mengajar. Sementara untuk mengatasi kendala dalam motivasi belajar siswa, guru berusaha memberikan motivasi pentingnya belajar bagi siswa pada akhir kegiatan dan memberikan appresiasi baik berupa penambahan nilai maupun hadiah bagi siswa yang ditunjuk untuk menjawab pertanyaan dan maju ke depan kelas dalam praktek percakapan.

\section{Simpulan dan Saran}

Berdasarkan pada hasil penelitian dan pembahasan, maka simpulan dari penelitian ini adalah:

(1) Pembelajaran ekstrakurikuler Japanese Club di SMK Nusa Dua Toya Anyar meliputi pemilihan konten materi yang masih berhubungan dengan materi yang pernah diajarkan sebelumnya pada mata pelajaran bahasa Jepang, dan bahan ajar dirancang secara mandiri oleh guru atau diperoleh dari berbagai sumber. Metode pembelajaran yang digunakan oleh guru adalah metode Grammar Translation Method digunakan ketika menjelaskan tentang kosakata dan pola kalimat bahasa Jepang. Strategi pembelajaran yang digunakan oleh guru yaitu strategi ceramah, diskusi, pemberian tugas, information gap, drill, dan role play.

(2) Kendala-kendala yang dihadapi dalam kegiatan ekstrakurikuler Japanese Club di SMK Nusa Dua Toya Anyar Kubu antara lain keterbatasan sarana dan prasarana pelajaran, kendala mengenai alokasi waktu, kendala dalam penguasaan materi oleh siswa, kendala dalam mengelola kelas, dan kendala kurangnya motivasi siswa dalam mengikuti kegiatan ekstrakurikuler.

(3) Upaya yang dilakukan untuk mengatasi kendala pembelajaran dengan cara pembangunan ruangan praktik oleh sekolah, melakukan penugasan, mengatur siswa Jurnal Pendidikan Bahasa Jepang | 30 
antar jurusan untuk duduk berpasangan, memberikan teguran bagi siswa yang tidak disiplin, dan memotivasi siswa tentang pentingnya belajar bahasa asing.

Berdasarkan temuan selama melaksanakan penelitian ini, maka akan disampaikan beberapa saran, yakni sebagai berikut.

(1) Dalam proses pembelajaran, ditemukan banyak kendala yang dihadapi baik oleh guru maupun oleh siswa, namun dengan adanya kendala, seharusnya mampu menjadi tantangan oleh para pendidik agar selalu meningkatkan kualitas pendidikan demi tercapainya tujuan pendidikan.

(2) Guru sebagai pendidik harus mampu menemukan metode dan strategi pembelajaran yang tepat dan sesuai dengan kemampuan siswa, menguasai materi ajar, dan menemukan media pengajaran yang menarik dan inovatif agar peserta didik dapat memahami materi dengan cepat serta tidak jenuh. Guru harus bisa mengatur manajemen waktu dengan baik, sehingga proses pembelajaran yang terjadi dapat berlangsung dengan efektif. Guru juga harus memotivasi siswa agar selalu semangat dan giat belajar, karena pada dasarnya guru dianggap sosok teladan di sekolah.

(3) Penelitian ini hanya sebatas mengenai profil pembelajaran ekstrakurikuler bahasa Jepang yang dilakukan di SMK Nusa Dua Toya Anyar Kubu. Dengan keterbatasan yang terdapat pada penelitian ini, diharapkan peneliti lain bisa menggali lebih dalam mengenai pembelajaran ekstrakurikuler terutama ekstrakurikuler yang berkaitan dengan bahasa Jepang di sekolah lain.

\section{Daftar Pustaka}

Kayi. 2006. "Teaching Speaking: Activities to Promote Speaking in a Second Language". The Internet TESL Journal, Vol. XII, No. 11.

Larsen-Freeman, Diane. 2000. Techniques and Principles in Language Teaching. Oxford: Oxford University.

Roestyah. 2008. Strategi Belajar Mengajar. Jakarta: Rineka Cipta.

Baroroh, Kiromim. 2011. "Upaya Meningkatkan Nilai-Nilai Karakter Peserta Didik Melalui Penerapan Metode Role Playing". Jurnal Ekonomi dan Pendidikan Universitas Negeri Yogyakarta. Volume 8, Nomor 2. 